\title{
Evaluasi Penerapan Spesifikasi Umum Pada Lapisan Pondasi Perkerasan Lentur
}

\author{
Ella Nurhayati ${ }^{1}$, Akhmad Suraji ${ }^{2}$, Benny Hidayat ${ }^{3}$ \\ Program Magister Teknik Sipil, Universitas Andalas ${ }^{1,2,3}$ \\ Email: ellanurhayati993@gmail.com¹, akhmad.suraji@gmail.com² ${ }^{2}$, bennyhidayat@eng.unand.ac.id ${ }^{3}$ \\ DOI: http://dx.doi.org/10.31869/rtj.v4i2.2383
}

\begin{abstract}
Perkerasan jalan sering mengalami kerusakan sebelum umur rencana yang disebabkan oleh mutu material lapis pondasi rendah dan kepadatan lapis pondasi yang tidak tercapai. Perlunya evaluasi penerapan terhadap spesifikasi teknis atau spesifikasi umum yang harus dilakukan sejak awal konstruksi sampai pasca konstruksi agar proyek tersebut mencapai mutu yang diinginkan. Penelitian bertujuan untuk mengetahui tingkat penerapan Spesifikasi Umum sebagai standar rujukan dalam dokumen kontrak pada pekerjaan perkerasan dan untuk mengetahui apa saja hambatan dalam pencapaian mutu perkerasan. Penelitian dilakukan melalui observasi lapangan, wawancara/kuesioner dengan variabel penelitian adalah material, pelaksanaan, hasil pengujian, sdm dan peralatan. Responden penelitian adalah kontraktor,konsultan dan pengawas PU. Hasil penelitian menunjukkan untuk tingkat penerapan telah 100\% memenuhi Spesifikasi Umum pada kedua paket. Untuk hasil tingkat kesulitan/hambatan pada Paket Pembangunan Jalan Teluk Bayur - Nipah Purus DAK (P.098) Kota Padang menurut kontraktor,konsultan dan pengawas PU adalah Cash Flow perusahaan dengan tingkat kesulitan masing - masing 61\%,68\% dan 53\%. Pada Paket Pembangunan Jalan Pasar Baru - Alahan Panjang DAK (P.073) Kab. Pesisir Selatan tingkat kesulitan/hambatan tertinggi menurut kontraktor adalah kesulitan memahami substansi standar mutu dengan nilai 43\%, menurut konsultan adalah kurangnya pelatihan keahlian dan keterampilan dalam metoda konstruksi dengan nilai 57\% dan menurut pengawas PU adalah keterbatasan quarry yang mempunyai izin dengan nilai $79 \%$.
\end{abstract}

Keywords: jalan, pekerjaan, penerapan, spesifikasi umum, tingkat

\section{PENDAHULUAN}

Jalan merupakan prasarana transportasi darat yang memegang peranan yang sangat penting dalam sektor perhubungan, terutama untuk kesinambungan distribusi barang dan jasa maupun perpindahan manusia yang dianggap paling efisien dan murah (Munggarani, 2017). Jaringan jalan nasional dan propinsi sebagaimana diamanatkan dalam Undang - Undang Republik Indonesia Nomor 38 Tahun 2004 tentang Jalan, memiliki peranan yang amat penting terhadap peningkatan perekonomian wilayah.

Kerusakan jalan merupakan salah satu permasalahan kompleks yang terjadi hampir di setiap daerah di Indonesia. Tidak jarang kerusakan jalan ini terjadi sebelum masa akhir rencana umur jalan (Munggarani, 2017). Beberapa terdapat jalan yang rusak sebelum waktunya (jalan tersebut baru berumur setengah dari rencananya). Hal ini terjadi karena pelaksanaan yang tidak sesuai dengan prosedur yang telah ditetapkan oleh Dirjen Bina Marga (Adiwijaya, 2017). mengakibatkan singkatnya umur rencana jalan, dengan kata lain umur rencana pasca konstruksi tidak dapat terpenuhi. Dan kesesuaian bahan dan alat juga harus dikerjakan mengikuti standar atau spesifikasi teknis pelaksanaan pekerjaan karena pekerjaan konstruksi yang baik dapat dihasilkan dari penggunaan material dan peralatan yang sesuai dengan spesifikasi teknis.

Perkerasan jalan sering mengalami kerusakan sebelum umur rencana yang disebabkan oleh mutu material lapis pondasi rendah dan kepadatan lapis pondasi yang tidak tercapai. Instruksi kerja yang mengacu pada spsesifikasi umum Direktorat Jenderal Bina Marga, yang disusun sebagai panduan dalam pengawasan pelaksanaan pekerjaan konstruksi jalan, sangat diperlukan agar pekerjaan konstruksi lapis pondasi agregat jalan dapat dilaksanakan sesuai metode kerja dan benar (Muballigh dkk, 2018). Keadaan ini ditemui pada jalan perkerasan lentur yang rentan terhadap kerusakan. 
Dari beberapa hasil penelitian di atas dapat diambil kesimpulan bahwa terdapat ketidaksesuaian pelaksanaan konstruksi perkerasan terhadap spesifikasi teknis atau spesifikasi umum yang digunakan, yang mengakibatkan tidak tercapainya penerapan standar mutu yang baik dan tepat pada konstruksi perkerasan jalan. Oleh karena itu, perlunya evaluasi penerapan terhadap spesifikasi teknis atau spesifikasi umum yang harus dilakukan sejak awal konstruksi sampai pasca konstruksi agar proyek tersebut mencapai mutu yang diinginkan.

Pekerjaan pembangunan Jalan Teluk Bayur - Nipah - Purus Kota Padang merupakan upaya untuk meningkatkan mutu pelayanan sarana pembangunan jalan provinsi yang mana sampai saat ini ruas jalan yang dimaksud belum terhubung dengan sempurna dimana pada kondisi jalan sudah ada perkerasan lama, namun belum ada pengaspalan dan kerusakan akibat umur rencana jalan yang sudah habis. Jalan Teluk Bayur - Nipah - Purus ini juga merupakan akses jalan menuju Kawasan Wisata Pantai Air Manis Atau Batu Malin Kundang yang merupakan kawasan objek wisata, dengan tujuan pembangunan jalan menuju akses wisata ini sesuai dengan penerapan spesifikasi teknis agar memberikan pelayanan jalan yang baik bagi pengunjung. Seperti halnya paket Pembangunan Jalan Pasar Baru - Alahan Panjang juga digunakan untuk moda transportasi masyarakat antar daerah ke daerah lain, yang mana sampai saat ini ruas jalan yang dimaksud belum terhubung dengan sempurna. Dengan adanya pembangunan jalan ini agar dapat dimanfaatkan sesuai pelayanan jalan yang diinginkan.

Adapun tujuan dari penelitian ini adalah untuk menentukan tingkat penerapan spesifikasi umum sebagai standar rujukan dalam dokumen kontrak pada pekerjaan perkerasan dan untuk menentukan apa saja hambatan dalam penerapan spesifikasi umum.

\section{METODE \\ PENELITIAN}

Penelitian ini dilakukan dengan cara Observasi Lapangan, Wawancara dan Kuesioner. Observasi Lapangan dilakukan untuk mengetahui tingkat penerapan Spesifikasi Bina Marga, sedangkan kuisioner dan wawancara dilakukan untuk validasi hasil observasi lapangan dan mengetahui apa saja hambatan / kesulitan dalam pencapaian mutu perkerasan. Responden penelitian ini adalah orang - orang yang berhubungan dengan proyek tersebut. Responden berjumlah 10 orang per paket pekerjaan. Penelitian ini dilakukan pada 2 paket pembangunan jalan yaitu Pembangunan Jalan Pasar Baru Alahan Panjang DAK (P.073) Kab. Pesisir Selatan dan Pembangunan Jalan Teluk Bayur - Nipah - Purus DAK (P.098) Kota Padang. Jika pelaksanaan di lapangan telah sesuai Spesifikasi Bina Marga, maka diperoleh tingkat penerapan $100 \%$ dan untuk mendapatkan nilai dari tingkat kesulitan yaitu diambil dari rata - rata, nilai tersebut dijadikan tingkat kesulitan dalam penerapan Spesifikasi Umum. Setelah didapat rata - rata tingkat kesulitan, maka akan dilakukan perangkingan. Dari hasil perangkingan akan didapat hambatan apa yang paling tinggi dalam penerapan Spesifikasi Umum tersebut Dari hasil observasi lapangan akan didapat tingkat penerapan, dapat dilihat pada gambar berikut :

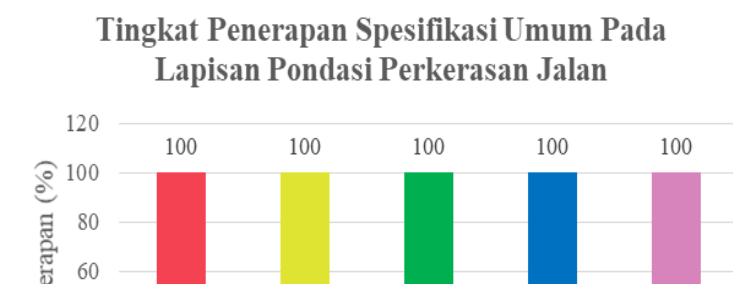

Gambar 1. Grafik Hasil Penelitian dari Observasi Lapangan

Dari gambar diatas dapat dilihat pada pekerjaan Paket Pembangunan Jalan Teluk Bayur - Nipah - Purus DAK (P.098) Kota Padang, tingkat penerapan dari masing masing variabel penelitian yaitu :

1. Bahan atau material yang digunakan dalam pelaksanaan menunjukkan tingkat penerapannya $100 \%$, penerapan pada bahan atau material yang disyaratkan sudah memenuhi persyaratan yang ada dalam Spesifikasi Umum 2018.

2. Tingkat penerapan dalam pelaksanaan juga menunjukkan $100 \%$ artinya pelaksanaan

3. keahlian dan keterampilan metoda konstruksi Kurangnya sosialisasi

4. pembaharuan Spesifikasi pada pekerjaan di lapangan juga telah 
sesuai dengan persyaratan teknis yang disyaratkan, telah sesuai dengan Rencana Mutu Kerja atau Kerangka Acuan Kerja(KAK).

3. Dari hasil pengujian pekerjaan di lapangan yaitu pengujian kepadatan, hasilnya Keterbatasan peralatan yang $\mathbf{1}$ sesuai standar yang bahwa hasil pengujian juga telah sesuai dengan persyaratan yang disyaratkan.

\section{HASIL DAN PEMBAHASAN}

Dari hasil observasi lapangan yang dilakukan pada kedua proyek, maka diperoleh masing - masing hasil tingkat penerapannya sebagai berikut :Paket Pembangunan Jalan Teluk Bayur -Nipah - Purus DAK (P.098) Kota Padang

\section{Tingkat Penerapan Spesifikasi Umum} 2018

Untuk tingkat penerapan sumber daya manusia (SDM) juga menunjukkan 100\%, sudah sesuai yang disyaratkan dalam Kerangka Acuan Kerja. Tingkat penerapan pada peralatan juga telah $100 \%$ memenuhi persyaratan sesuai dengan Rencana Mutu Kerja dan Kerangka Acuan Kerja.

\section{Tingkat Kesulitan / Hambatan} dalam Pencapaian Mutu Perkerasan Jalan Tingkat kesulitan / hambatan dengan data sebagai berikut :

\section{a.Persepsi Kontraktor}

Dari hasil penilaian 5 responden yang berasal dari kontraktor dengan wawancara dan kuesioner. Maka didapat penilaian untuk tingkat kesulitan/ hambatan seperti grafik dibawah ini :

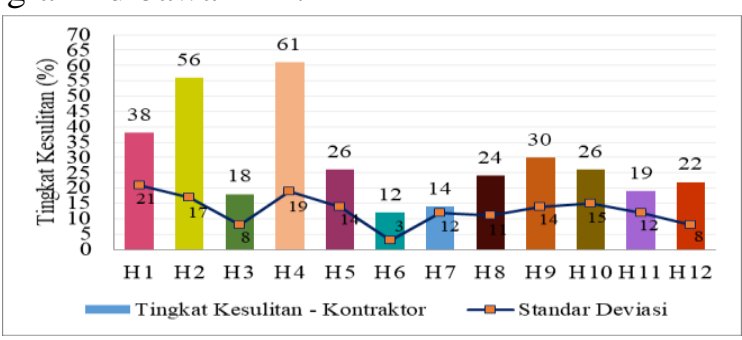

Gambar 2. Grafik Tingkat

Kesulitan atau Hambatan

Penilaian Kontraktor

Dari gambar diatas dapat dilihat menurut kontraktor tingkat kesulitan atau hambatan pada variabel $\mathrm{H} 4$ atau cash flow perusahaan didapat nilai paling tertinggi $61 \%$ dengan standar deviasi 19\%. Dalam pelaksanaan pekerjaan membutuhkan biaya yang cukup besar dalam pelaksanaan, jika cash flow perusahaan atau aliran dana tidak lancar maka akan menghambat dalam proses pelaksanaan pekerjaan atau kemajuan progres pelaksanaan dalam pencapaian mutu pekerjaan yang baik.

\section{b. Persepsi Konsultan}

Dari hasil penilaian responden konsultan. Maka didapat penilaian untuk tingkat kesulitan/ hambatan seperti grafik dibawah ini :

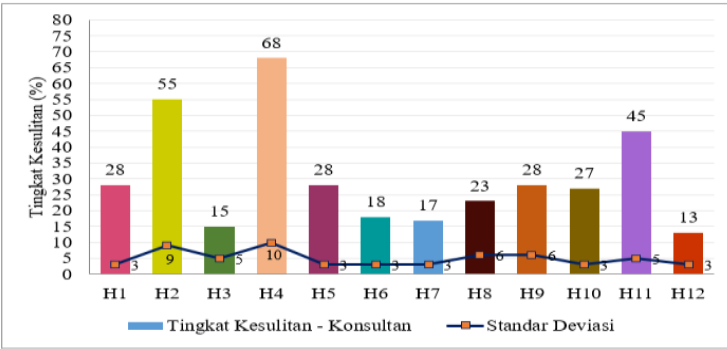

Gambar 3. Grafik Tingkat

Kesulitan/Hambatan Penilaian Konsultan

Dari gambar diatas dapat dilihat menurut konsultan untuk tingkat kesulitan atau hambatan didapat nilai yang paling tertinggi adalah $68 \%$ pada variabel $\mathrm{H} 4$ yaitu pada tingkat kesulitan cash flow perusahaan dengan standar deviasi $10 \%$, cash flow perusahaan merupakan pengendali mutu yang penting dalam hal biaya pelaksanaan jika cash flow perusahaan tidak lancar maka akan berdampak terhadap pelaksanaan pekerjaan yang sedang berlangsung.

\section{c. Persepsi Pengawas PU}

Dari hasil penilaian responden yang berasal dari Pengawas PU. Maka didapat penilaian untuk tingkat kesulitan/ hambatan seperti grafik dibawah ini :

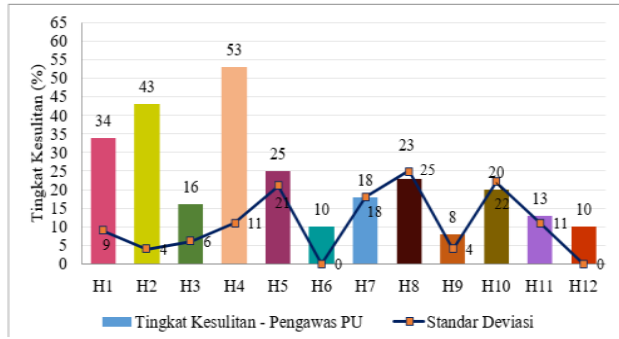

Gambar 4. Grafik Tingkat

Kesulitan/Hambatan Penilaian Pengawas PU

Dari gambar diatas dapat dilihat menurut pengawas PU untuk tingkat 
kesulitan/hambatan juga didapat nilai yang paling tertinggi yaitu 53\% sama dengan halnya persepsi dari kontraktor dan konsultan. Cash flow merupakan salah satu indikator terpenting dalam pencapaian mutu pekerjaan, jika cash flow perusahaan atau biaya tidak lancar maka akan menghambat dalam proses pelaksanaan pekerjaan yang sedang berjalan.

\section{- Paket Pembangunan Jalan Pasar Baru Alahan Panjang Dak (P.073) Kab. Pesisir Selatan}

\section{Tingkat Penerapan Spesifikasi Umum}

Dari hasil observasi lapangan akan didapat tingkat penerapan, dapat dilihat pada gambar berikut :

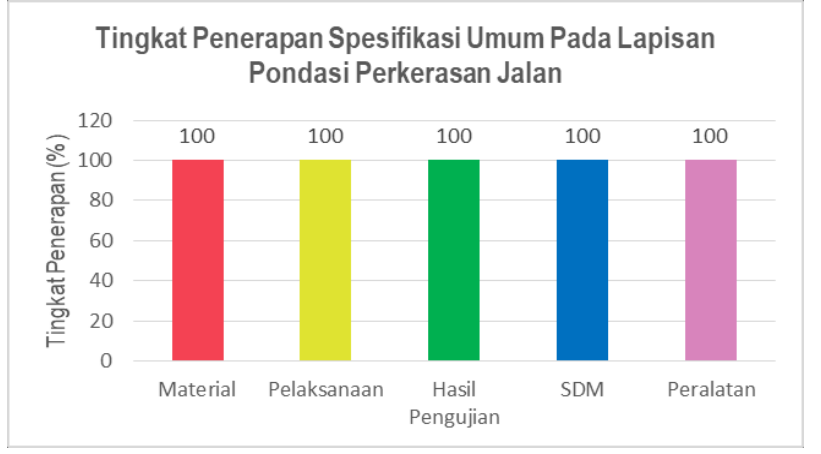

Gambar 5. Grafik Hasil Penelitian dari Observasi Lapangan

Dari gambar diatas dapat dilihat pada pekerjaan Paket Pembangunan Jalan Pasar Baru Alahan Panjang (P.073) Kab. Pesisir Selatan, untuk tingkat penerapan dari masing - masing variabel penelitian yaitu :

1. Bahan atau material yang digunakan dalam pelaksanaan menunjukkan tingkat penerapannya $100 \%$, penerapan pada bahan atau material yang disyaratkan sudah memenuhi persyaratan yang ada dalam Spesifikasi Umum 2018.

2. Tingkat penerapan dalam pelaksanaan juga menunjukkan $100 \%$ artinya pelaksanaan pada pekerjaan di lapangan juga telah sesuai dengan persyaratan teknis yang disyaratkan, telah sesuai dengan Rencana Mutu Kerja atau Kerangka Acuan Kerja (KAK).

3. Dari hasil pengujian pekerjaan di lapangan yaitu pengujian kepadatan, hasilnya menunjukkan $100 \%$ bahwa hasil pengujian juga telah sesuai dengan persyaratan yang disyaratkan.

4. Untuk tingkat penerapan sumber daya manusia (SDM) juga menunjukkan
$100 \%$, sudah sesuai yang disyaratkan dalam Kerangka Acuan Kerja.

2. Tingkat Kesulitan / Hambatan dalam Pencapaian Mutu Perkerasan Jalan

Tingkat kesulitan / hambatan dengan data sebagai berikut :

\section{a. Persepsi}

Maka didapat penilaian untuk Kontraktor Dari hasil penilaian dari kontraktor dengan wawancara dan kuesioner tingkat kesulitan/ hambatan seperti grafik dibawah ini :

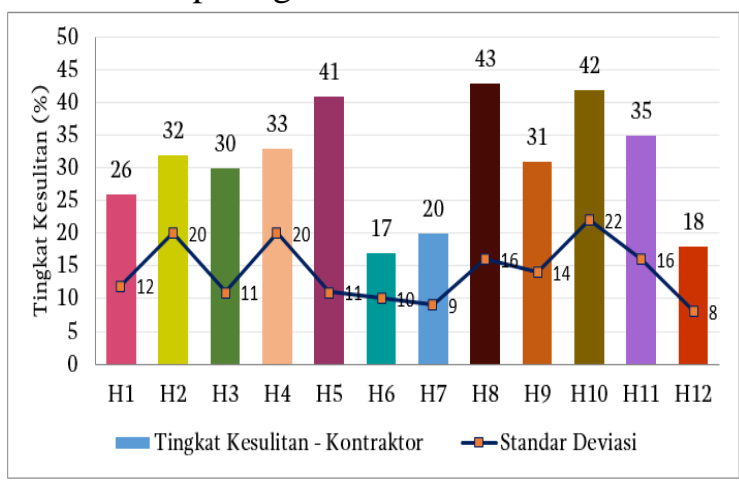

Gambar 6. Grafik Tingkat Kesulitan atau

Hambatan Penilaian Kontraktor

Dari gambar di atas dapat dilihat menurut kontraktor tingkat kesulitan / hambatan tertinggi dalam pencapaian mutu perkerasan yaitu pada variabel $\mathrm{H} 8$ atau kesulitan memahami substansi standar mutu dengan nilai tertinggi yaitu 43\%. Dikarenakan bahasa dalam spesifikasi umum yang sedikit berbelit

- belit dan adanya rasa malas membaca dari spesifikasi umum yang cukup tebal membuat

beberapa individu tidak begitu paham dengan metode - metode pelaksanaan yang ada pada spesifikasi umum.

\section{b. Persepsi Konsultan}

Dari hasil penilaian konsultan dengan wawancara dan kuesioner. Maka didapat penilaian untuk tingkat kesulitan/ hambatan seperti grafik dibawah ini : 


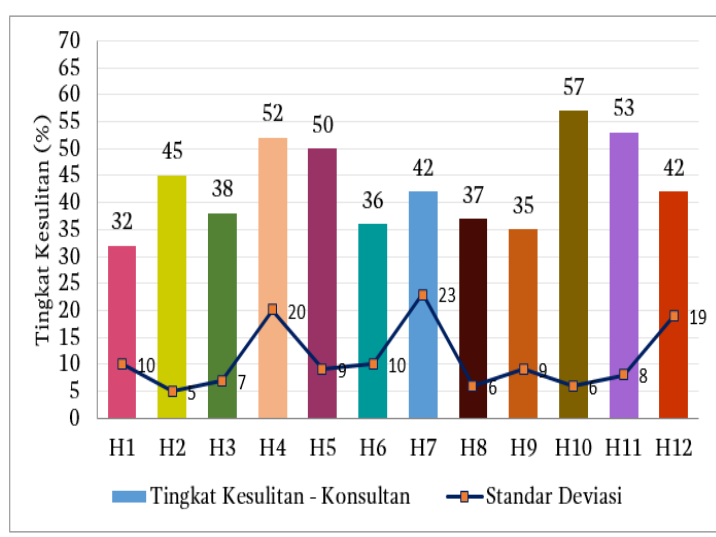

Gambar 7. Grafik Tingkat Kesulitan atau Hambatan Penilaian Konsultan

Dari gambar diatas dapat dilihat, bahwa variabel H10 atau kurangnya pelatihan keahlian dan keterampilan metoda konstruksi didapat nilai tertinggi dengan nilai $57 \%$ dengan standar deviasi 6\%, menurut konsultan terbatasnya penyampaian informasi ketika adanya pelatihan, sehingga hanya orang orang tertentu atau orang yang tergabung dalam asosiasi yang mendapatkan informasi dan terbatasnya juga dalam hal biaya jika pelatihan diadakan diluar daerah sendiri.

\section{c. Persepsi Pengawas PU}

Dari hasil wawancara dan kuesioner ke Pengawas PU, maka didapat penilaian untuk tingkat kesulitan/ hambatan seperti grafik dibawah ini :

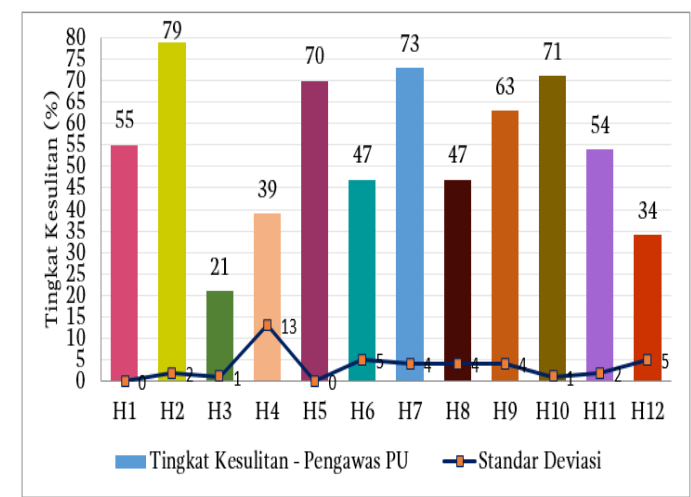

Gambar 8. Grafik Tingkat Kesulitan atau Hambatan Penilaian Pengawas PU

Dari gambar diatas dapat dilihat, bahwa variabel $\mathrm{H} 2$ atau Material atau keterbatasan quarry mempunyai izin didapat nilai tertinggi dengan nilai $79 \%$ dengan standar deviasi $2 \%$, menurut pengawas PU keterbatasan quarry mempunyai izin, dikarenakan sulitnya mendapatkan izin tambang karena syarat pengambilan material harus ditempat yang mempunyai izin. Hal ini membuat proyek -proyek lain juga ikut mengambil di satu tempat quarry yang memiliki izin tersebut, sehingga mengakibatkan volume material yang diinginkan menjadi tidak tercapai dan berakibat mencari sumber material dari tempat lain yang beberapa tidak sesuai dengan mutu yang diharapkan.

\section{PENUTUP}

Berdasarkan analisa dan pembahasan yang sudah dilakukan maka dapat disimpulkan sebagai berikut :

1. Untuk tingkat penerapan pada paket Pembangunan Jalan Teluk Bayur - Nipah - Purus DAK (P.098) Kota Padang dari masing - masing variabel penelitian sudah memenuhi persyaratan yang ada pada Spesifikasi Umum dengan tingkat penerapannya $100 \%$.

2. Untuk tingkat penerapan pada paket Pembangunan Jalan Pasar Baru - Alahan Panjang DAK (P.073) Kab. Pesisir Selatan dari masing - masing variabel penelitian sudah memenuhi persyaratan yang ada pada Spesifikasi Umum dengan tingkat penerapannya $100 \%$.

3. Tingkat kesulitan atau hambatan dalam pencapaian mutu yang paling tertinggi pada paket Pembangunan Jalan Teluk Bayur - Nipah - Purus DAK (P.098) Kota Padang berdasarkan hasil penilaian tingkat kesulitan atau hambatan responden dari kontraktor $61 \%$, dari konsultan $68 \%$, dan pengawas PU 53\%. Maka dari hasil penilaian tingkat kesulitan atau hambatan dari kontraktor, konsultan dan pengawas PU secara keseluruhan didapat nilai tertinggi pada cash flow perusahaan. Dalam pelaksanaan pekerjaan membutuhkan biaya yang cukup besar dalam pelaksanaan, jika cash flow perusahaan atau aliran dana tidak lancar maka akan menghambat dalam proses pelaksanaan pekerjaan atau kemajuan progress pelaksanaan.

4. Tingkat kesulitan atau hambatan dalam pencapaian mutu yang tertinggi pada paket Pembangunan Jalan Pasar Baru - Alahan Panjang DAK (P.073) Kab. Pesisir Selatan adalah :

a. Menurut kontraktor kesulitan atau hambatan dalam pencapaian mutu perkerasan dengan rata - rata tingkat 
kesulitan atau hambatan per indikator

pertanyaan didapat nilai paling tertinggi sebesar $43 \%$ yaitu kesulitan memahami substansi standar mutu

b. Menurut konsultan kesulitan atau hambatan dalam pencapaian mutu perkerasan dengan rata - rata tingkat kesulitan atau hambatan per indikator pertanyaan didapat nilai paling tertinggi sebesar $57 \%$ yaitu kurangnya pelatihan keahlian dan keterampilan metoda konstruksi.

c. Menurut pengawas PU, kesulitan atau hambatan dalam pencapaian mutu perkerasan dengan rata - rata tingkat kesulitan atau hambatan per indikator pertanyaan didapat nilai paling tertinggi sebesar $79 \%$ yaitu menurut pengawas PU keterbatasan quarry mempunyai izin.

\section{DAFTAR PUSTAKA}

Adiwijaya. (2017). Pengaruh Kualitas Sumber Daya Manusia Dalam Mencapai Mutu Pekerjaan Konstruksi Jalan Lentur. Jurnal Vol. 3 No 01, Badan Pengembangan Sumber Daya Manusia. Kementerian Pekerjaan Umum dan Perumahan Rakyat.

Dirjen Bina Marga, (2010). Statistik Jalan Nasional dan Propinsi. Jakarta : Departemen Pekerjaan Umum.

Haryono, T., (2005). SNI on Line dan Dampaknya Terhadap Permintaan Standar. Jurnal Standarisasi Vol. 7 No 2 : 45-49, ISSN 1441-0822. Badan Standarisasi Nasional (BSN). Jakarta.

Muballigh., Mulyono, T. A., (2018). Penerapan Sistem Manajemen Mutu Pelaksanaan Pekerjaan Lapis Pondasi Agregat Pada Jalan Provinsi Di Provinsi Jawa Tengah. Jurnal Transportasi Vol. 18 No. 2 Agustus 2018: 77 - 86. Universitas Gajah Mada.

Mulyono, T, A., Santosa, W., Asikin Z, M., Ardhiarni, R., (2010). Evaluasi Penggunaan SNI Sebagai Standar Rujukan Dalam Penyelenggaraan Infrastruktur Jalan. Konferensi Nasional Teknik Sipil 4 (KoNTekS 4). Sanur - Bali.

Mulyono, T. A. (2006). Kinerja Pemberlakuan

Standar Mutu Perkerasan Pada Peningkatan Dan Pemeliharaan Jalan Nasioanl - Propinsi. Pusat Studi
Transportasi dan Logistik (PUSTRAL). Yogyakarta. Universitas Gadjah Mada.

Munggarani, A, N., Wibowo, A. (2017). Kajian Faktor - Faktor Penyebab Kerusakan Dini Perkerasan Lentur dan Pengaruhnya Terhadap Biaya Penanganan. Jurnal Infrastruktur Vol. 3 No. 01 Juni 2017. (Thesis Magister), Konsentrasi Manajemen Proyek Konstruksi Dosen Sekolah Pascasarjana Universitan Katolik Parahyangan.

Peraturan Menteri Pekerjaan Umum. (2012).Tata Cara Pengawasan Jalan. Menteri Pekerjaan Umum Republik Indonesia. Spesifikasi Umum. (2018). Untuk Pekerjaan Konstruksi Jalan dan Jembatan.

Kementerian Pekerjaan Umum dan Perumahan Rakyat. Direktorat Jenderal Bina Marga. Susanti, R., (2018). Analisis Terhadap Variabel Yang Mempengaruhi Pemberlakuan Standar Mutu Pada Pekerjaan Pemeliharaan Jalan Di Propinsi Banten. Jurnal Fondasi, Volume 7 No 1. Jurusan Teknik Sipil UniversitasTarumanegara. 